\title{
The impact of organizational trust on psychological contract fulfillment in the Private Sector educational Environment in Egypt
}

\author{
By: \\ Dr. Ayman Mobarez \\ Assistant professor in CIC \\ School of business \\ Dr/ Noha MagdyKamel \\ Assistant professor in CIC \\ School of business
}

$$
\begin{aligned}
& \text { إعداد } \\
& \text { د. أيمن عبد العال مبارز } \\
& \text { مدرس إدارة الأعمال بالمعهد الكندي العالي للإدارة } \\
& \text { د. نها مجدي كامل الثعراوي } \\
& \text { مدرس إدارة الأعمال بالمعهد الكندي العالي للإدارة }
\end{aligned}
$$




\section{The impact of organizational trust on \\ Dr. Ayman Mobarez}

\section{$\underline{\text { Abstract }}$}

This research aimed to investigate the structural model between organizational trust and psychological contracts between employees and academic staff members in the private educational and learning organization in Egypt, (Canadian international college CIC).

This research is crucial if management researchers are to move forward on other approaches to understanding educational and learning organization as we first must understand how employee feels about their respective Organization. The study method is descriptive correlation.

The study population is the employee of the CIC in Egypt employees are selected by simple random method and sampling table (Krejcie \& Morgan, 1970).

The study used Pearson correlation coefficient structural equations modeling.

The result of the study showed a positive significant relationship between organizational trust (OT) and psychological contracts (PC). Also the positive relation to the related variables of competency, openness \& honesty, and reliability and PC fulfillment.

$$
\begin{aligned}
& \text { هدف هذا البحث إلى دراسة النموذج الهيكلي بين النقة التنظيمية والعقود النفسية بين الموظفين وأعضاء }
\end{aligned}
$$

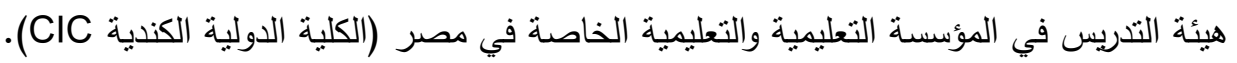

$$
\begin{aligned}
& \text { يعد هذا البحث أمرًا ضروريًا إذا أراد باحثّ الإدارة المضي قدمًا في مناهج أخرى لفهم المؤسسة } \\
& \text { التعليمية والتعلمية حيث يتعين علينا أولاً أن نفهم كيف بشعر الموظف تجاه منظمتهم. } \\
& \text { طريقة الدراسة هي العلاقة الوصفية. ، مجتمع الدراسة هو موظف CIC في مصر ، ويتم اختيار } \\
& \text { موظفيها بطريقة عشوائية بسيطة وجدول أخذ العينات ( Krejcie \& Morgan، 1970) استخدمت الدراسة } \\
& \text { ندذجة المعادلات الهيكلية لمعامل بيرسون. }
\end{aligned}
$$

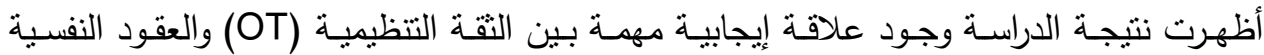

$$
\begin{aligned}
& \text { (PC) }
\end{aligned}
$$

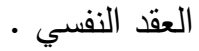




\section{The impact of organizational trust on \\ Dr. Ayman Mobarez}

\section{$\underline{\text { Introduction }}$}

Investigating the topic of trust is a continuing concern within the scholar's and practitioners interests. The management based on trust is a new expression of the old thoughts, and practicing it in the current relations and implementing it effectively will lead to collaboration among groups, people and well results in achieving good organizations results (Jones \& George, 1998). Fitzroy, (2007) argue that it is important for all organization managers and employees to underline their role of trust and establish their relations based on it, and consider its importance. Trust refers to the positive expectations of the organizations members about Openness and honesty, competence and reliability toward their Interpersonal and Institutional trust of their organization (Mayer et al., 1995). Moreover, trust refers to the relationship between organizations and employees regarding measuring employee perceptions towards organization managers. (Khanifar et al., 2009). One of the priorities of each organization now a day is responding to the employee's basic needs and one most important needs for and employee is establishing organizational trust toward their organization (Khanifar et al., 2009). Vakola \& Bouradas, (2011). Defined organizational trust as "psychological sta te providing a feedback of how employees perceive the problems in the situations in which the organization is endangered".

In order for organizations to understand its individual trust we must relate it to the psychological contract as both variables are linked to each other's. The focus of this study is how organizational trust relates to psychological contracts. In fact, researchers are recognizing the importance of social exchange as a theoretical foundation for understanding the relationship between individuals and their organization (Coyle-Shapiro \& Neil Conway, 2005). 


\section{The impact of organizational trust on \\ Dr. Ayman Mobarez}

Over the past century there has been a dramatic change in the organizations in order to compete in the marketplace. Working in a competitive and difficult work environment has made changes between the internal arrangements of the relationship between employees and the organization known as the nature of psychological contracts. One of the most important assets in the organization are Employees, therefore, in order to retain these asset, the organization need to understand and fulfill what the employees expects from the organization ,s side and accomplish it. (Festing and Schafer, 2014). Written contract must always exist between both the organization and employee; however, psychological contract represents more implicit and wider nature of the written contract (Roehling, 1997). Roehling, (1997) argues that psychological contracts nature imply that employees have expectations must be fulfilled by their organizations, and the organization have expectations must be fulfilled by their employees respectively. Psychological contracts clarify the mutual relationship between both the organization as well as the employee.

In their right, responsibility's, obligations, duties and expectations (Rousseau, 1989).

\section{Problem Statement:}

There has been an increasing interest in both organizational trust and in psychological contract describing the relationship between organizations and employees. However, so far there has been less attention of linking both research areas together. Even though, other researcher has examined these relations for example. Argento \& Peda (2015) argued that organizational trust and psychological contract are complementary to each other's among individuals and organizations in keeping their shared interests aligned. Also trust and contract have been highlighted to be one on the main common success between employee and their organizations.

Therefore, this research represents a great contribution to the current literature and also provides important results regarding the 


\section{The impact of organizational trust on \\ Dr. Ayman Mobarez}

prioritization of the strategic directions to be followed in the organizations toward their employees. Finlay, this research will also provide important results demonstrated on the following relation to these important core variables

\section{Research Questions}

1. What is the relationship between organizational trust and psychological contracts in the educational organizations?

2. Does an organizational trust construct provide a stronger prediction of psychological contracts when compared to the prediction of the underlying organizational trust dimensions: competence, openness/honesty, and reliability in the educational organization?

This question addresses whether organizational trust and psychological contracts are in fact related, and will be compared with the underlying sub hypothesis.

\section{Hypothesis}

H1: Organizational trust is positively related to psychological contracts in the educational organization.

H1a: Competence is positively related to psychological contracts.

H1b: Openness and honesty is positively related to psychological contracts.

H1c: Reliability is positively related to psychological contracts.

\section{$\underline{\text { Research Objectives }}$}

1- Understand what the relationship is between organizational trust and psychological contracts in the educational organization.

2- To determine if the inter-organizational trust construct provides a stronger prediction of psychological contracts when compared to the prediction of the underlying inter organizational trust 


\section{The impact of organizational trust on \\ Dr. Ayman Mobarez}

dimensions: competence, openness/honesty, concern, reliability in educational organizational.

3- Seek if an availability of alternatives affects the relationship between inter organizational trust and psychological contracts

\section{Research Importance}

1- The results from this research fill a gap in the research literature and offer scholars and practitioners insight into organizational trust and psychological contracts between members in the educational organizational.

2- This research is important as educational and learning organizational are organizations that are critically important that work at the interface of society and industry and surprisingly little research has been performed to understand them.

3- This research also determined that, within the context of educational organization and their members, an organizational trust construct provides a stronger prediction of psychological contracts when compared to the prediction of the underlying organizational trust dimensions: Competence, openness/honesty, concern, reliability, and identification in educational and learning organizational.

\section{LITERATURE REVIEW}

There has been much of evidence highlighting the importance of organizational trust and psychological contracts both in theory and in practice, describing the relationship between organizations and employees. In the same way, this study will explore the organizational trust and psychological contracts that employee in CIC higher institute for Business and engineering have towards their Organization. The assumption is that employees enter trust-based relationships expecting a mutually beneficial exchange, and therefore the employee of CIC (Canadian International Collage) joins the organization for a similar mutually beneficial relationship. 


\section{The impact of organizational trust on \\ Dr. Ayman Mobarez}

The following section will demonstrate the literature for the organizational trust and psychological contract.

\section{Organizational Trust:}

Trust:

Trust, can be defined as one's "expectations or beliefs regarding the likelihood that another's future actions will be favorable, or at least not detrimental, to one's interests" (Morrison and Robinson, 1997, p. 238).

Rousseau and Tijoriwala (1999) found that trust in management was positively related to the perceived legitimacy of reasons for the change and, as demonstrated by Oreg (2006), trust in manageme nt is related to lower levels of affective, behavioral and cognitive resistance to a change. Additionally, Devos et al. (2007) found that trust in executive management as well as in the direct supervisor significantly contributed to the openness of employees to organizational change. This study therefore predicts that change recipients' trust in their organization and its representatives is positively related to an employee's attitude toward a specific organizational change.

By operationalizing attitude toward change as a multidimensional construct, and examining engagement, psychological contract fulfillment and trust to represent the prechange internal context.

The perceived obligations that constitute the psychological contract are based on promises (Rousseau, 2001) that are made either explicitly or implicitly (Rousseau, 1989). Violations of perceived promises diminish the trust of employees in their employer (Robinson and Rousseau, 1994; Robinson, 1996). Because trust lies at the heart of the employment relationship (Guest, 2004), the effects of an under fulfillment of the psychological contract can be detrimental for the performance of individual employees, and thus for the organization as anwhole. By contrast, psychological contract fulfillment may create 


\section{The impact of organizational trust on \\ Dr. Ayman Mobarez}

commitment (Coyle-Shapiro and Kessler, 2000) and employee satisfaction (Tekleab et al., 2005). Although limited, there is also support for the positive relationship between psychological contract fulfillment and engagement (Chambel and Oliveira-Cruz, 2010), so that the present study expects that:. Psychological contract fulfillment is positively related to (a) engagement and (b) trust

Establishing of organizational trust is still a big challenge confronting each organization; trust can be categorized as the basic component of effective social process between organization members. Trust represents and effective predictor of employee's positive behavior, such as organizational commitment, employee loyalty, and organizational citizenship behavior. Therefore, establishing organizational trust for employees represents an ideal goal for any organization (Molm, Collett, and Schaefer 2007).

Social exchange theory state that, the more organizational trust the employee's gets the more effort employee will provide to the organization. Resulting in more motivation to work hard, increase energy and engaging in positive behavior (Blau, P.M, 1964). Ekvall and Ryhammar (1999) argued that if employees perceive the climate of trust and new the mutual trust relationship between them and the organization, they will act in more positive and low risk behaviors toward their organization. Moreover, Barczak, et al. (2010) stated that if the surrounding environment of the employee is trustworthy, they well feel friendly with other members in the organization, and therefore, will result in positive discussion and generate more useful and innovative ideas. Other studies, like Aryee et al. (2002) and Knippenberg and Schie (2000) have found that trust will make employee contribute and cooperate with each other and though will result in motivation of employee to work harder to complete task and inspire more motivated ideas. Liu, Loi, and Lam's (2011) in their study of organizational trust have found the positive relation between trust and OCB and also have found the impact of trust of the employee 


\section{The impact of organizational trust on \\ Dr. Ayman Mobarez}

efficiency and attitude. Moreover, a consensus between researchers have found that trust is vital for all organizational activities such as goal setting, cooperation with team members, leadership, and teamwork, (Shockley-Zalabak, Ellis \& Winograd 2000; Axelrod, 1984; Elangovan \& Shapiro, 1998; Gambetta, 1988; Jones \& George, 1998; Mayer, Davis, \& Schoorman, 1995; McAllister, 1995; Dibben, 2000; Velez \& Strom, 2012). Limerick and Cunnington, (1993) argues that; "trust is the key value in networking, and is the one that is most problematic" and that trust "lubricates the smooth harmonious functioning of the organization by eliminating the friction and minimizing the need for bureaucratic structures." (Caldwell, 2001). Also trust, can be defined as one's "expectations or beliefs regarding the likelihood that another's future actions will be favorable, or at least not detrimental, to one's interests" (Morrison and Robinson, 1997, p. 238).

Trust represents an important issue in the interpersonal relationship in the work environment if any organization also for both managers and professionals In the organization (McAllister, 1995).. Porter et al,. (1975) state that "where there is trust there is the feeling that others will not take advantage of me". However, this study focuse on the employee's trust towards their organization's outhoritier such as, managers, leaders and supervisors (Brockner et. al., 1997).

\section{$\underline{\text { Research Objectives }}$}

Understand what the relationship is between organizational trust and psychological contracts in the inter-organizational context.

To determine if the inter-organizational trust construct provides a stronger prediction of psychological contracts when compared to the prediction of the underlying inter organizational trust dimensions: competence, openness/honesty, concern, reliability in educational organizational. 


\section{The impact of organizational trust on \\ Dr. Ayman Mobarez}

Seek if an availability of alternatives affects the relationship between inter organizational trust and psychological contracts

\section{LITERATURE REVIEW}

There has been much of evidence highlighting the importance of organizational trust and psychological contracts both in theory and in practice, describing the relationship between organizations and employees. In the same way, this study will explore the organizational trust and psychological contracts that employee in CIC higher institute for Business and engineering have towards their Organization. The assumption is that employees enter trust-based relationships expecting a mutually beneficial exchange, and therefore the employee of CIC (Canadian International Collage) joins the organization for a similar mutually beneficial relationship.

The following section will demonstrate the literature for the organizational trust and psychological contract.

This literature review also describes how organizational trust and psychological Contracts are related and have been determined to be interchangeable constructs, and just as organizational trust diminishes so happens a breach in the psychological contract. Lowered trust and broken psychological contracts lead to lower contribution by the employee, and by extension the association member.

In our model, employees, customers and members are three distinct entities.

The model will depict the relationship between organizational trust and psychological contracts of the employee of CIC Three variables previously established as a viable measurement of organizational trust, four variables to measure psychological contracts and one variable to determine if the availability of alternatives is related to organizational trust and psychological contracts. Rousseau 


\section{The impact of organizational trust on \\ Dr. Ayman Mobarez}

(1995), Robinson, (1996) and Mayer, Davis \& Schoorman (1995)

definition' are used to define the constructs of psychological contracts and organizational trust in this research.

Research on the topic of psychological contracts and organizational trust since Rousseau and Robinsons' definition has been widespread and thousands of scholarly articles are available.

A 2017 Harvard Business Review Article notes for 17 years the Edelman's Trust Barometer, performed by a large public relations firm, results show for the first-time levels of trust in business, media government and Non-Governmental Agencies (GMOs) are all in decline.

Edelman's had surveyed tens of thousands of people in dozens of countries about their levels of trust (Harrington, 2017).

The constructs of psychological contract and organizational trust, as inter-changeable constructs, have been and continue to be a focus of interest for researchers and practitioners alike

Psychological Contracts:

Psychological contract fulfillment.

A large and growing body of literature has investigated the topic of psychological contract introduced by Argyris (1960) . Argyris highlighted that there is a psychological contract between both employers and employees; however he didn't clarify the type of contract this relation was about, and didn't concrete a specific definition for the following concept. After Argyris, numerous studies have attempted to explain and define the concept of psychological contract. For example Rousseau (1995), lustrate the contract as a subjective perception of an individual toward others, however, it doesn't relate to the reality but it is how the reality is perceived by the employee. This subjective aspect is represented in Rousseau's definition of the psychological contract: which is "the individual's beliefs about mutual obligations, in the context of the relationship 


\section{The impact of organizational trust on \\ Dr. Ayman Mobarez}

between employer and employee" (Rousseau, 1990, p.391). Moreover, Robinson, Kraatz, \& Rousseau, (1994) has explained the obligations as the "beliefs, held by an employee or employer, that each in bound by promise or dept. to an action or course of action in relations to the other party" these beliefs are described as the interaction between the organization agents for example (supervisors, recruiters, managers of the HR department) and the employees (Rousseau, 2001). In conclusion, the employee will have beliefs towards their organization's obligations, as well as, the obligations of employee toward their organization (Koh \& Yer, 2000). So the psychological contract clarifies and explains the mutual relationship between both the employer and the employee.

Finally, according to Smithson and Lewis (2003) although the deferent definition of the psychological contract has been referenced there should be main elements covered in any definition such as.

1. "Incorporation of beliefs, values, expectations and aspirations of employer and employee, including beliefs about implicit promises and obligations, the extent to which these are perceived to be met or violated and the extent of trust within the relationship."

2. "These expectations are not necessarily made explicit. It can be regarded as the implicit deal between employers and employees. It implies fairness and good faith."

3. "An important aspect of the notion of a psychological contract is that it can be continually re-negotiated, changing with an individual's, and an organization's, expectations, and in shifting economic and social contexts. It is not static, but dynamic and shifting."

4. "Because it is based on individual perceptions individuals in the same organization or job may perceive different psychological contracts, which will, in turn, influence the ways in which they perceive organizational events." (p. 71) 


\section{The impact of organizational trust on \\ Dr. Ayman Mobarez}

\section{Psychological Contract Measure:}

To measure psychological contracts, four items developed by Tekleab and Taylor (2003), similar to Robinson et al. (1994), were used.

Tekleab and Taylor measured the psychological contract, determining if the "Company" had fulfilled its obligations to the employee just as the "Employee" has fulfilled their obligation to the company. For the purpose of this study the scale was a 5 -point Likert measurement.

\section{Organizational Trust:}

Trust between individuals (employees, the investing public, and shareholders) and organizations has been recognized as a critical variable for long-term financial success, yet this organizational trustworthiness has been threatened by questionable behaviors of political and corporate leaders (Caldwell, \& Clapham, 2003).

Trust is present when others are perceived as trustworthy (Meyer, Davis, \& Schoorman, 1995).

At the interpersonal level as noted by Mayer, Davis and Schoorman (1995), trust is extended to those who demonstrate ability or competence, benevolence or respect for the best interest of another, and integrity or congruent and honest behavior.

Establishing of organizational trust is still a big challenge confronting each organization; trust can be categorized as the basic component of effective social process between organization members. Trust represents and effective predictor of employee's positive behavior, such as organizational commitment, employee loyalty, and organizational citizenship behavior. Therefore, establishing organizational trust for employees represents an ideal goal for any organization (Molm, Collett, and Schaefer 2007). 


\section{The impact of organizational trust on \\ Dr. Ayman Mobarez}

Social exchange theory state that, the more organizational trust the employee's gets the more effort employee will provide to the organization. Resulting in more motivation to work hard, increase energy and engaging in positive behavior (Blau, P.M, 1964). Ekvall and Ryhammar (1999) argued that if employees perceive the climate of trust and new the mutual trust relationship between them and the organization, they will act in more positive and low risk behaviors toward their organization. Moreover, Barczak, et al. (2010) stated that if the surrounding environment of the employee is trustworthy, they well feel friendly with other members in the organization, and therefore, will result in positive discussion and generate more useful and innovative ideas. Other studies, like Aryee et al. (2002) and Knippenberg and Schie (2000) have found that trust will make employee contribute and cooperate with each other and though will result in motivation of employee to work harder to complete task and inspire more motivated ideas. Liu, Loi, and Lam's (2011) in their study of organizational trust have found the positive relation between trust and OCB and also have found the impact of trust of the employee efficiency and attitude. Moreover, a consensus between researchers have found that trust is vital for all organizational activities such as goal setting, cooperation with team members, leadership, and teamwork, (Shockley-Zalabak, Ellis \& Winograd 2000; Axelrod, 1984; Elangovan \& Shapiro, 1998; Gambetta, 1988; Jones \& George, 1998; Mayer, Davis, \& Schoorman, 1995; McAllister, 1995; Dibben, 2000; Velez \& Strom, 2012). Limerick and Cunnington, (1993) argues that; "trust is the key value in networking, and is the one that is most problematic" and that trust "lubricates the smooth harmonious functioning of the organization by eliminating the friction and minimizing the need for bureaucratic structures." (Caldwell, 2001). Also trust, can be defined as one's "expectations or beliefs regarding the likelihood that another's future actions will be favorable, or at least not detrimental, to one's interests" (Morrison and Robinson, 1997, p. 238). 


\section{The impact of organizational trust on \\ Dr. Ayman Mobarez}

Trust represents an important issue in the interpersonal relationship in the work environment if any organization also for both managers and professionals In the organization (McAllister, 1995).. Porter et al,. (1975) state that "where there is trust there is the feeling that others will not take advantage of me". However, this study focuse on the employee's trust towards their organization's outhoritier such as, managers, leaders and supervisors (Brockner et. al., 1997).

Despite the numerous definitions of trust by scholars over the years the academic

literature generally agrees that interpersonal trust is a dyadic relationship between two parties (Mayer, Davis, \& Schoorman, 1995; Caldwell \& Jeffries, 2001) and is frequently described in conte xt with the continuum of beliefs to action (Caldwell, 2001).

In these dyadic relationships, interpersonal trust plays a significant role in creating an organizational environment that fosters cooperation based upon the moral qualities of effective managerial leadership (Caldwell, 2001;Fayol 1949; \& Putnam, 1992).

Mary Parker Follet and Chester Irving Barnard were two early scholars who wrote on the relationship of trust and interpersonal effectiveness in organizations in the first part of the twentieth century.

Follet discussed the importance of cooperation in restructuring the relationship

between labor and management although treating trust and cooperation were separate but related constructs.

Barnard (1938) noting communication and trust are linked to perceptions of overall In her work Follet emphasized that organizations would be more "effective if their leaders dealt with employees in a manner that engendered followership based upon trust rather than focusing on command and control" (Caldwell, 2001 p. 20., Graham, 1995). 


\section{The impact of organizational trust on \\ Dr. Ayman Mobarez}

Ring and Van de Ven (1994) propose that individual trust is required for inter-company trust, as organizations do not trust, but individuals do.

Furthermore Hult, Stafford, Walker \& Reingen (2000) found trust to be one of the key areas that significantly affect relationships and that it is dependent on communication, honesty and the integrity or underlying motives of individuals (Das \& Teng, 2001).

Trust enables people to take risks: "where there is trust there is the feeling that others will not take advantage of me" (Porter et al., 1975, p. 497).

Trust is founded on the expectation that one will find what is expected rather than what is feared (Deutsch, 1973). Many times, the individuals trust is centered on how they make decisions that affect how they behave: "Do they consider my interests and welfare?" These ideas together result in a definition of interpersonal trust as the extent to which a person is confident in, and willing to act based on, the words, actions, and decisions of another (McAllister, 1995).

Although trust is important in organizational interpersonal relationships (McAllister, 1995), the focus here is on employee's trust for people in authority positions, such as their immediate supervisor or members of upper management (Brockner et. al., 1997). Studies have shown that employees trust in their organization's authorities affect work attitudes and behaviors in a variety of ways (Trussell, 2015). Generally, employees are more supportive and commitment-orientated to the organization the authorities represent.

This support and commitment to authorities and their organizations are presented in a variety of ways (Brockner et. al., 1997). Subordinates who feel supportive of their

organizational authorities are likely to be:

(a). satisfied with the relationship with their authorities. 


\section{The impact of organizational trust on \\ Dr. Ayman Mobarez}

(b). committed to the organization and its goals,

(c). behave in accordance to further the goals of authorities and the organization (Zagenczyk et.al., 2011). Konovsky \& Pugh (1994) found employees were more apt to show evidence of organizational citizenship when they trusted their supervisors.

The importance of trust and trustworthiness to an organization in achieving its goals is nothing new.

Downsizing, rightsizing, globalization, an increase in diversity, technological advances, decentralized decision making, and misuse of power by executives making decisions are only a few events and processes making trust a significant topic of study in organizations and cultures (Ellis, et.al., 2000, Zia \& Khan, 2014; Harrington, 2017). Trust and trustworthiness within and across organizations is argued by many to be directly related to the ability to form new associations and networks of trusting relationships to achieve organizational goals and predictive of whether an organization will remain viable (ShockleyZalabak, Ellis, et. al., 2000).

Furthermore, a consensus among researchers concludes that trust is important in organizational activities such as teamwork, leadership, goal setting and arguably cooperative behavior in general (Shockley-Zalabak, Ellis \& Winograd 2000; Axelrod, 1984; Elangovan \& Shapiro, 1998; Gambetta, 1988; Jones \& George, 1998; Mayer, Davis, \& Schoorman, 1995; McAllister, 1995; Dibben, 2000; Velez \& Strom, 2012).

The study of trust has been noted as necessarily vital because of the interdependence of people and organizations (Caldwell, 2001; Daley 1991; Nyhan \& Marlowe, 1997).

Caldwell further notes with the information age combined with the importance of intellectual capital have increased the need for trust in relationships. An article in Fortune Magazine (Sept. 1998) noted 


\section{The impact of organizational trust on \\ Dr. Ayman Mobarez}

that over half of a firm's perceived value in many industries is from its "smart people" or intellectual capital.

When these people become fed up with their boss, they quit and take this intellectual capital with them. Finding talented people to replace them is time consuming and cost intensive.

Limerick and Cunnington, (1993) state; "trust is the key value in networking, and is the one that is most problematic" and that trust "lubricates the smooth harmonious functioning of the organization by eliminating the friction and minimizing the need for bureaucratic structures." (Caldwell, 2001).

Ironically Reina and Reina (1998) noted that there was a growing decline in trust in

society despite its critical importance. This irony that trust is of critical importance and growing in significance, yet poorly defined and diminishing in society, makes it clear that clarifying the terms trust and trustworthiness and research of its place in Industry is crucial to the future of business and society (Caldwell, 2001). Business Week's June 24, 2002, cover story titled "Restoring Trust in Corporate America" featured a series of stories that thoroughly discussed problems associated with the breakdown in corporate trustworthiness, the impact of the breakdown on the perceptions of the public, and what measures need to be taken to restore trust

in corporate America. The stories went on about an "endless stream of bad news alleging widespread management negligence and malfeasance is chipping away at the trust vital to a freemarket system" (para. 4) and accused many leaders of corporate America of "egregious breaches of trust and abuse of power" (para. 4). Trust has continued to decline in business, media, government and NGOs, since Reina and Reina (1999) using the Edelman Trust Barometer, reported that a 17-year international study had shown for the first-time that trust declined in all 


\section{The impact of organizational trust on \\ Dr. Ayman Mobarez}

organizational types (Harrington, 2017).

\section{Organizational trust measure:}

A survey instrument titled the Organizational Trust Index (OTI) was used to measure the 5 dimensions of organizational trust (Shockley-Zalabak, Morreale et. al., 2010). The Organizational Trust Index was developed by researchers and practitioners funded by a grant from the International Association of Business Communicators Research Foundation.

Openness and honesty:

"Openness and honesty is reflected in how organizations communicate about problems, engage in constructive disagreements, and provide input into job-related decisions". (Shockley- Zalabak et. al., 2010). Honesty as a construct of trust is a mediating variable in psychological contracts (Krishnan, Marinich \& Shields, 2012).

\section{Competence:}

Competence is "the ability of the organization through its leadership, strategy, decisions, quality, and capabilities to meet the challenges of its environment". (Shockley-Zalabak et. al., 2010). Competence is measured by the organizations ability to meet its objectives and as a component of trust is reflected in the evaluation of psychological contracts (Isaksson et.al. 2003)

\section{Reliability:}

The reliability dimension is about commitment and doing what the trade association says it is going to do. Organizational reliability and predictability, per leading psychological contract researchers, is critical in the development of trust among stakeholders (Robinson and Rousseau 1994; Baksh, 2010) 


\section{The impact of organizational trust on \\ Dr. Ayman Mobarez}

Relationship between Organizational Trust, and Psychological Contracts:-

Trust is the positive expectation of the behavior of the other (Hosmer 1995), also psychological contracts is the unwritten trust based agreements between both the employee and the employer in the consensus between the contributions of both side obligations toward each other (Rousseau, 1995).

Suffering from psychological contracts breach will results in less contribution between the respondent and the organization because they feel that they no longer trust the organization, and therefore, will ignore organization obligations and contract (Robinson, 1996). In another word, if the employee is treated in unfairness way, their contract will get breached resulting in diminishing in the employee's trust and therefore, will deteriorate their goals and obligation between them and their leader and managers.

Thus breached contract will results in less trust and thought lower contribution to organization obligation and requirements (Robinson, 1996).

Trust is interrelated with psychological contract meaning that when the employer promise to do something and then do another thing the employee trust will diminish toward his employer. And so as the psychological contract which is similarly related to the individual trust and beliefs shaped by the employee toward the employer and vice versa (Robinson, 1996). Trust and contract play a complementary vital role in the employment relationship.

Though in our proposition we can demonstrate that acquiring of organizational trust will result in the fulfillment of psychological contract in the educational organization as well as other originations. 
Figure 1

$\underline{\text { Research Model }}$

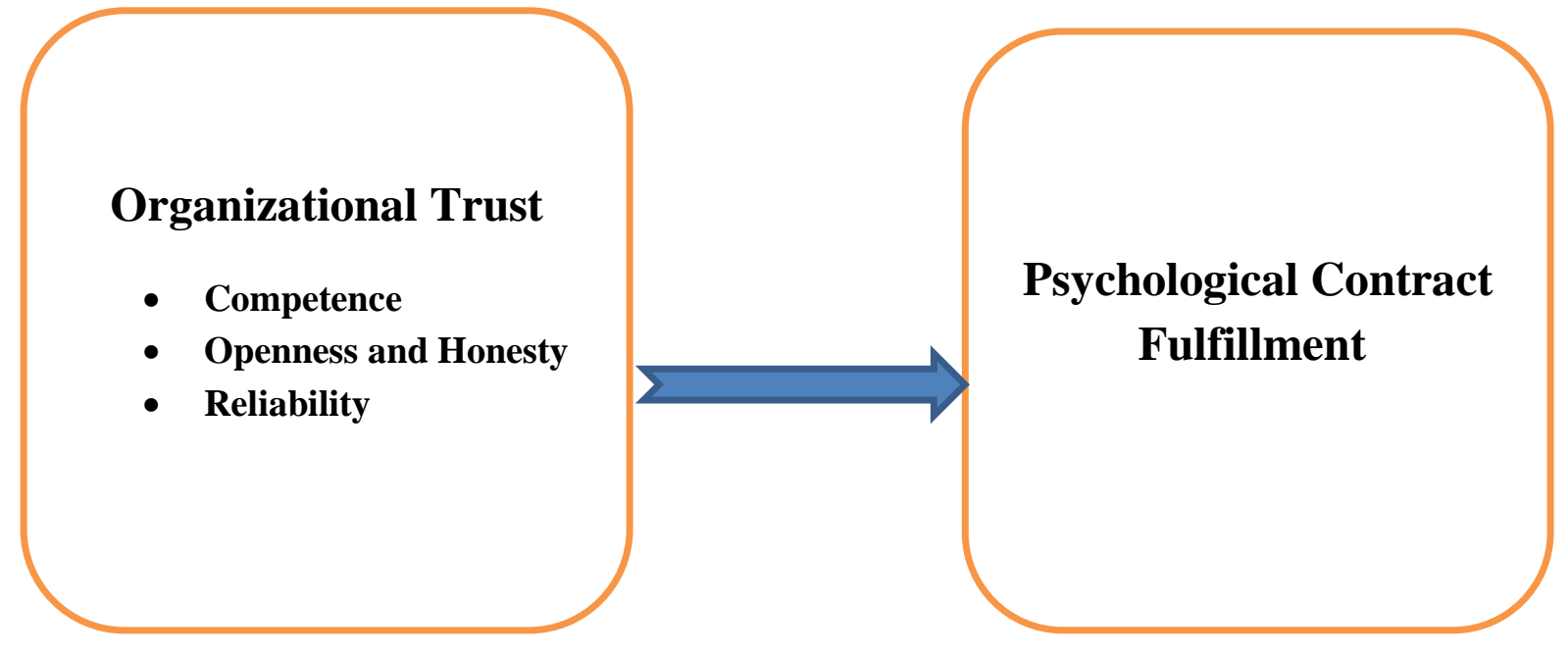

$\underline{\text { Population and sample }}$

\begin{tabular}{|c|c|c|c|}
\hline \hline New Cairo Branch & Elshikh Zayed Branch & Division & \\
& & & \\
\hline 55 & 35 & Academic Staff & 1 \\
\hline 85 & 40 & Assistant Staff & 2 \\
\hline 65 & 50 & Admin, Staff & 3 \\
\hline $\mathbf{2 0 5}$ & $\mathbf{1 2 5}$ & Total & \\
\hline
\end{tabular}

Table ( 1 )

(The source HRM in Zayed \& New Cairo -) 


\section{The impact of organizational trust on \\ Dr. Ayman Mobarez}

The target survey respondents are members of Canadian International; collage ( Shikh Zayed Branch and New Cairo Branch .

The sample consists of mostly all the members who range from Academic staff members (doctors) and assistant staff (TA,s \& LA,s ) and administration staff .This range of possible respondents offered an accurate group to collect a sufficient sample.

So the searchers will take all the respondents as sample (330 respondents) .

\section{Testing Validity and Reliability:}

\section{Examination Validity of Measurement:}

\begin{tabular}{|c|c|c|c|c|}
\hline $\begin{array}{c}\text { KMO } \\
\text { Bartlett's } \\
\text { (Test Sig ) }\end{array}$ & $\begin{array}{c}\text { Confirm } \\
\text { atory } \\
\text { Factor } \\
\text { Analysis }\end{array}$ & $\begin{array}{r}\text { Pearson } \\
\text { correlation }\end{array}$ & العبارة & r \\
\hline \multirow{4}{*}{$\begin{array}{l}.720 \\
.000\end{array}$} & \multicolumn{4}{|c|}{ Competence } \\
\hline & 918. & .924 & 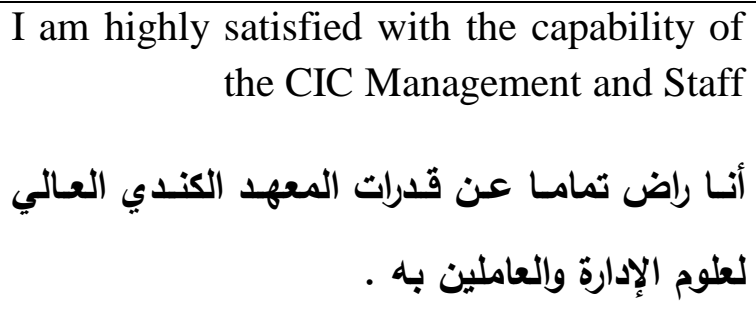 & .1 \\
\hline & .956. & .953 & $\begin{array}{l}\text { I am highly satisfied with the capacity of } \\
\text { the CIC organization to achieve its } \\
\text { objectives. } \\
\text { أنا راض للغاية عن قدرة هيئة CIC لتحقيق أهدافها }\end{array}$ &.$r$ \\
\hline & .864 & .866 & 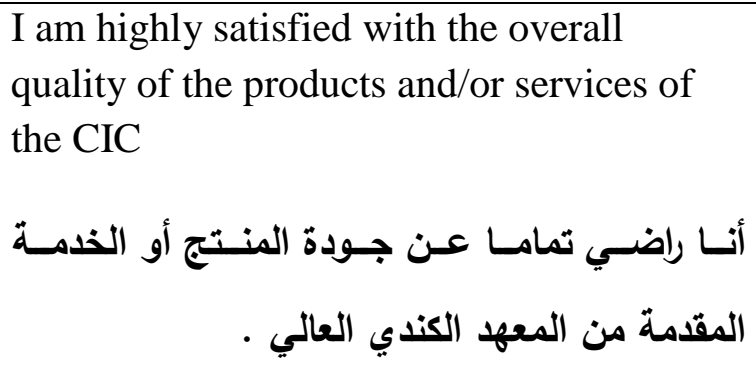 & r. \\
\hline
\end{tabular}




\section{The impact of organizational trust on \\ Dr. Ayman Mobarez}

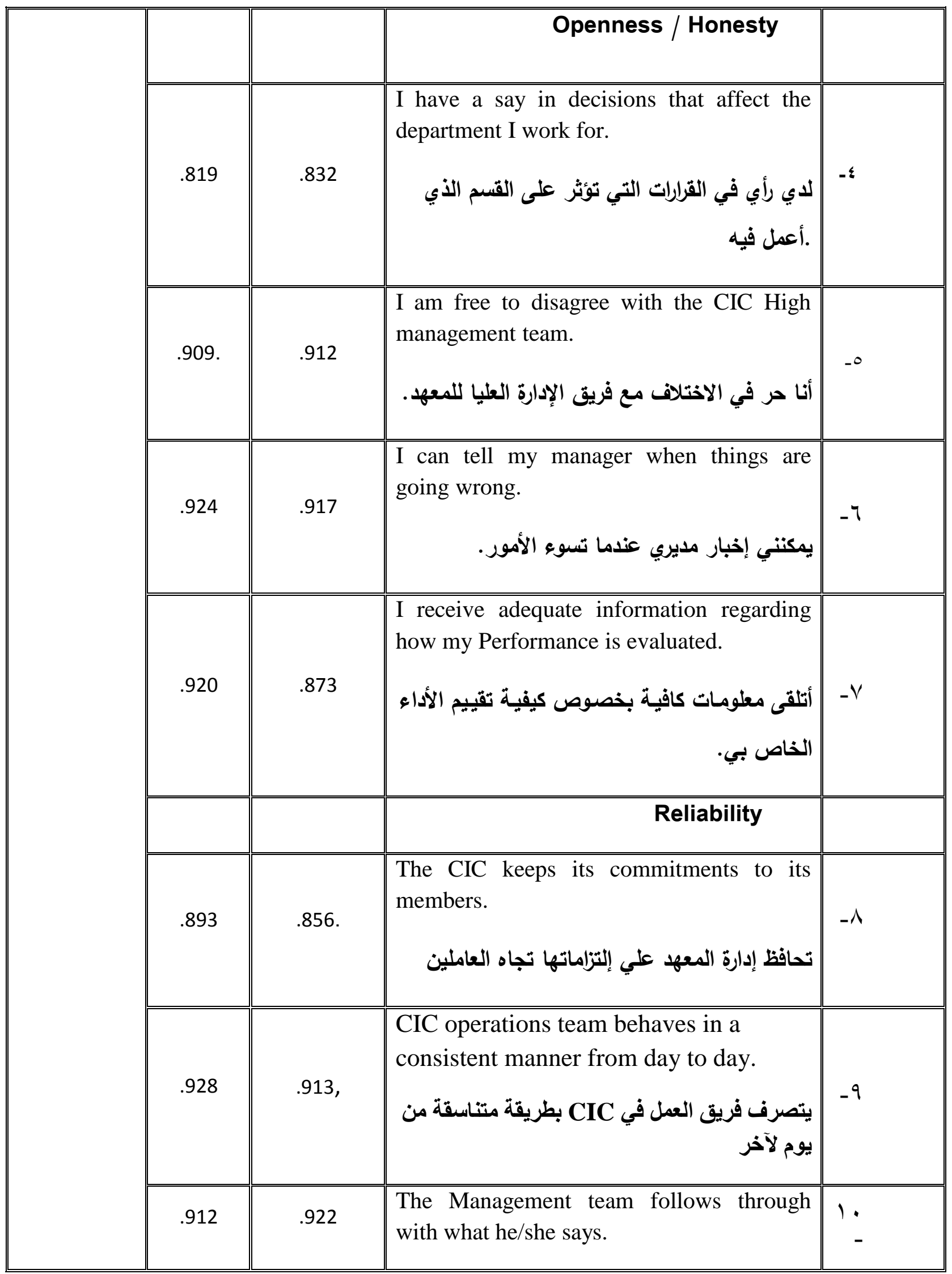




\section{The impact of organizational trust on \\ Dr. Ayman Mobarez}

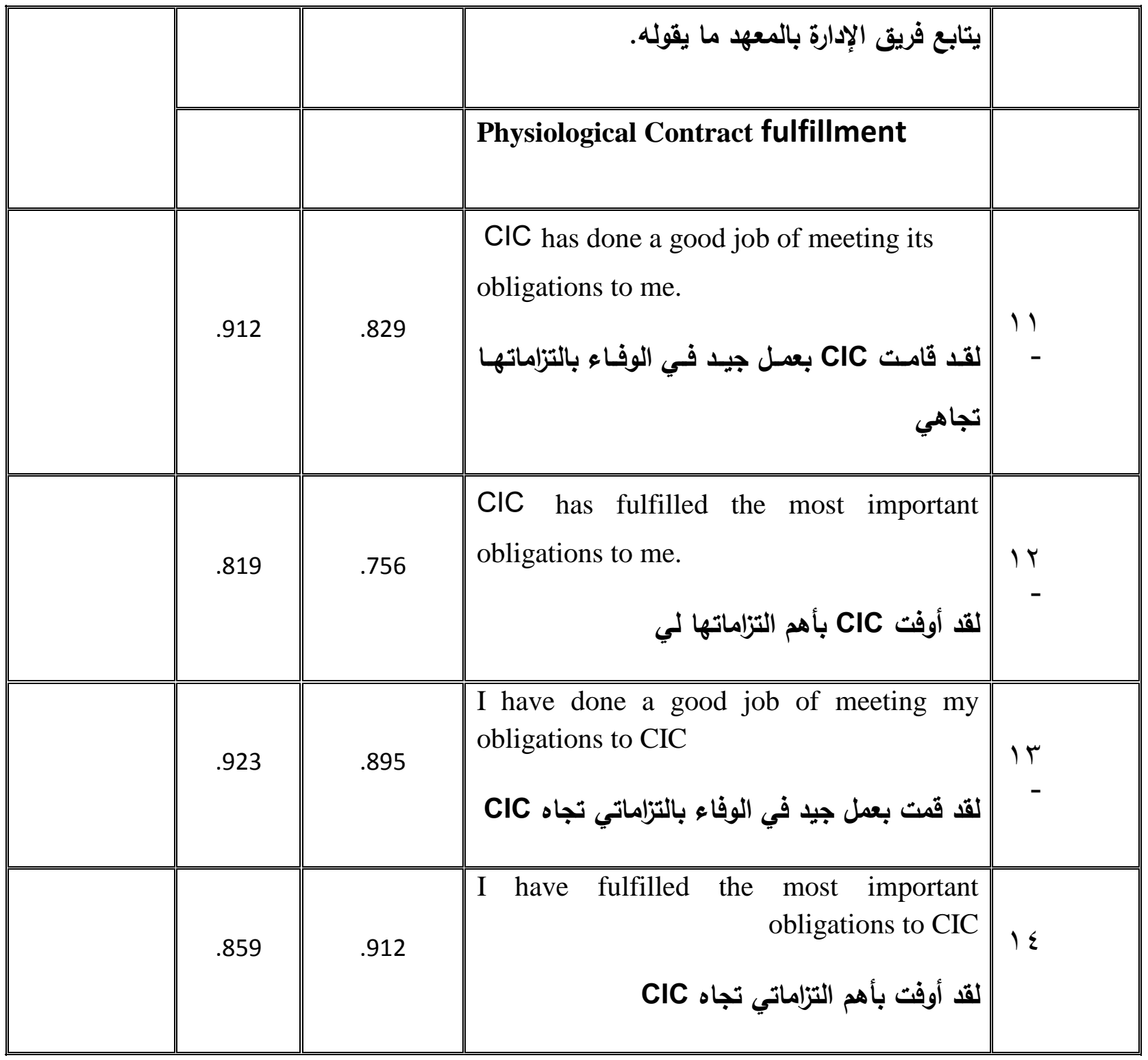

Table 2

Three tools were used to determine reliability of the measurement.

Cronbach's $\alpha, \&$ Confirmatory Factor Analysis -CFA Pearson correlation SLR

The Table reveals that all the values of Cronbach's $\alpha$ higher than

0.72, SLR from. 756 to .953 Confirmatory Factor Analyses -CFA from .819 to .956

Therefore the validity is fulfilled.

Examination Reliability of Measurement: 


\section{The impact of organizational trust on \\ Dr. Ayman Mobarez}

\begin{tabular}{|c|c|c|c|}
\hline Dimentions & $\begin{array}{c}\text { No, of } \\
\text { elements }\end{array}$ & Cronbach's $\alpha$ & \\
\hline Competence & 3 & .891 & $1-$ \\
\hline Openness / Honesty & 4 & .757 & $2-$ \\
\hline Reliability & 3 & .858 & $3-$ \\
\hline Physiological Contract fulfillment & 4 & .833 & $4-$ \\
\hline \hline .921 & $\mathbf{1 4}$ & \multicolumn{2}{|l|}{} \\
\hline
\end{tabular}

Table 3

The tool was used to determine reliability of the measurement. Cronbach's $\alpha$, it was greater than 0.9 reliability is considered acceptable, and in this case the results surpass the acceptable level demonstrating an excellent level of reliability

\section{Correlation:}

Correlation analysis was used as the first pass to review the relationship between variables. The aspired significance level of less than .05 was met, illustrating the results are significant and did not occur by chance. All variables are related (See Table ).

Table No 3 Pearson's Correlation Matrix,

\begin{tabular}{|c|c|c|c|c|c|}
\hline Scale & Org Trust & $\begin{array}{l}\text { PC } \\
\text { Index }\end{array}$ & Competence & Open/Honest & Reliability \\
\hline Org Trust & 1 & & & & \\
\hline PC Index & $.771 * *$ & 1 & & & \\
\hline Competence & $.894 * *$ & $.819 * *$ & 1 & & \\
\hline Open/Honest & $963^{* *}$ & $.806^{* *}$ & $.884^{* *}$ & 1 & \\
\hline Reliability & $.821 * *$ & $.826^{* * *}$ & $.917 * *$ & $.883 * *$ & 1 \\
\hline
\end{tabular}

** Correlations are significant at the 0.01 level (2-tailed) 


\section{The impact of organizational trust on \\ Dr. Ayman Mobarez}

Table 4

Examination of the Variables

\begin{tabular}{|l|ccc|c|c|}
\hline Scale & Org Trust & $\begin{array}{c}\text { PC } \\
\text { Index }\end{array}$ & Competence & Open/Honest & Reliability \\
\hline Mean & 3.40 & 3.62 & 3.57 & 3.38 & 3.66 \\
Median & .3 .41 & 3.50 & 3.50 & 3.33 & 3.50 \\
Std. Error & .09002 & .08311. & .10098 & .09541 & .08661 \\
Std. & .95416 & .79715. & .96854 & .91519 & .83076 \\
Deviation & &. & & \\
& & & & & \\
\hline
\end{tabular}

\section{-Regression Analysis :}

Regression analysis was used to test Hypotheses $1-2 . R^{2}$. Measures how close the data is to the regression line and Table 4.9 displays the $R^{2}$. Results. $R^{2}$., as a percentage, is always between 0 and 1 with 0 indicating the model explains none of the variability surrounds the mean and $1 \%$ indicating all for the variability of the response data is around the mean.

All constructs results span between $\approx 55 \%$ and $60 \%$ illustrating more than half of the data fits the model.

Generally, a higher $R^{2}$. Represents a better model fit but, in some instances, it is fine to have a lower $R^{2}$. Value. In fields attempting to predict human behavior, such as psychology, $R 2$ - values are expected to be lower, as humans are harder to predict than, for instance, physical processes (Frost, 2013). Arguably, the element of human behavior prediction in the psychological contracts constructs applies in this study. Aside from the $R^{2}$. According to Frost (2013), the coefficients "still represent the mean change in response for one unit of change in the predictor while holding other predictors in the model constant" (p. 1). For H1, for example, the Beta coefficient for Organizational Trust in the table is 0.667 . This means that for every one point increase in Organizational Trust, the model predicts that Psychological Contracts will increase by 0.667 points 


\section{The impact of organizational trust on \\ Dr. Ayman Mobarez}

\begin{tabular}{|c|c|c|c|c|c|c|c|c|}
\hline \multicolumn{9}{|c|}{ Table 5} \\
\hline $\begin{array}{l}\text { Regressio } \\
\mathrm{n} \\
\text { Option }\end{array}$ & $\begin{array}{l}\text { Independe } \\
\text { nt } \\
\text { Var-Y } \\
\text { Range }\end{array}$ & $\begin{array}{l}\text { Depen } \\
\text { nt } \\
\text { Var-X } \\
\text { Range }\end{array}$ & & $\begin{array}{l}\text { Statistic } \\
\text { al } \\
\text { Test }\end{array}$ & $\begin{array}{l}\text { R } \\
\text { Squar } \\
\text { e }\end{array}$ & $\begin{array}{l}\text { Beta } \\
\text { Coe } \\
\text { nt }\end{array}$ & ficie & $\begin{array}{l}\text { Significanc } \\
\mathrm{e} \\
P \text {-value }\end{array}$ \\
\hline Нyp 1 & \multicolumn{2}{|c|}{ Org Trust } & \multicolumn{2}{|c|}{ Psych Cont } & \multicolumn{2}{|c|}{ Linear Reg } & .59 & $\begin{array}{r}5.667 \\
p<.0001\end{array}$ \\
\hline $\begin{array}{l}\text { Hyp 1a } \\
\qquad p<.\end{array}$ & \multicolumn{2}{|c|}{01 Competence } & \multicolumn{2}{|c|}{ Psych Cont } & \multicolumn{2}{|c|}{ Linear Reg } & $p<.0001$ & .628 \\
\hline \multicolumn{2}{|c|}{$p<.0001$} & & \multicolumn{2}{|c|}{ Psych Cont } & \multicolumn{2}{|c|}{ Linear Reg } & & .612 \\
\hline $\begin{array}{l}\text { Hyp 1c } \\
\qquad p<.0\end{array}$ & \multicolumn{2}{|c|}{ Reliability } & \multicolumn{2}{|c|}{ Psych Cont } & \multicolumn{2}{|c|}{ Linear Reg } & .572 & .762 \\
\hline
\end{tabular}

Hypothesis 1. Organizational Trust is positively related to Psychological Contracts

Table 6

Table

Statistical Data Research Question 1 - Hypothesis 1

Org Trust - Psych Contracts Value Probability

$\begin{array}{lll}R^{2} & .595 & p<.0001\end{array}$

Pearson's Correlation $\quad .771 \quad p<.01$

Table -6 presents the statistical analyses to test Hypothesis 1. It shows the $\mathrm{R} 2$ as $.595, p$ value is highly significant $(p<.0001)$, and therefore the null hypothesis is rejected. In addition, while Pearson's Correlation (noted in Table 11) scored .771 with $p<.01$ indicating a strong linear association meaning as Psychological Contracts increases, Organizational Trust also increases. Figure 10 shows an $R^{2}$ $=0.595$, meaning the model (line) accounts for $60 \%$ of variability about the mean. 


\section{The impact of organizational trust on \\ Dr. Ayman Mobarez}

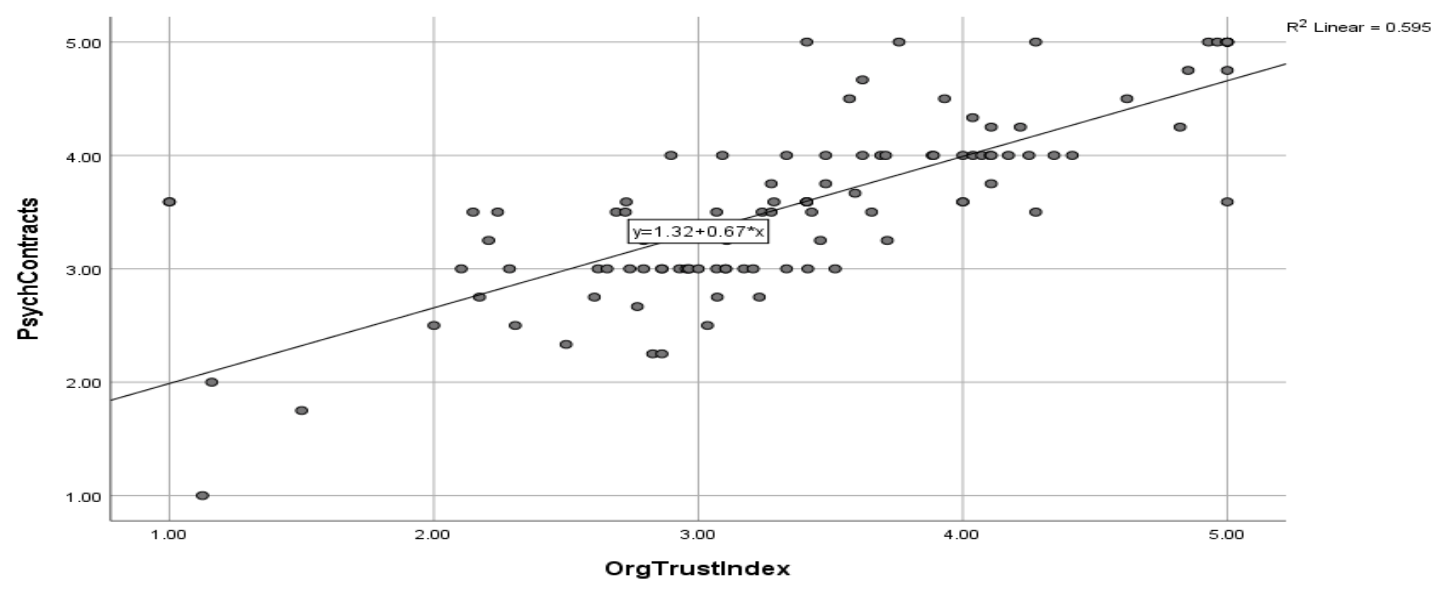

Figure 2.

Graph representing the relationship between Organizational Trust and Psychological Contracts. Scatter plot H1

Question 2. Does an organizational trust construct provide a stronger prediction of psychological contracts when compared to the prediction of the underlying organizational trust dimensions:

competence, openness/honesty, and reliability, in Educational Organization?

An $R^{2}$ analysis shows that the percent variance between organizational trust and psychological contracts do provide a stronger prediction when compared to the underlying trust dimensions (see Table ---- ).

Table 7

Comparison of organizational trust - psychological contracts dimensions $R$-values.

\begin{tabular}{lc}
\hline Constructs & $R^{2}$ \\
Percent & \\
Organizational Trust - Psychological Contracts & .595 \\
$60 \%$ & \\
Competence - Psychological Contracts & .586 \\
$59 \%$ & \\
$\begin{array}{l}\text { Openness/Honesty - Psychological Contracts } \\
55 \%\end{array}$ & .549 \\
$\begin{array}{l}\text { Reliability - Psychological Contracts } \\
57 \%\end{array}$ & .572 \\
\hline
\end{tabular}




\section{The impact of organizational trust on \\ Dr. Ayman Mobarez}

Table 8

Statistical Data Question 2 - Hypothesis 1a. Competence is positively related to Psychological Contracts

\begin{tabular}{|lcc|}
\hline $\begin{array}{l}\text { Competence }- \text { Psych Contracts } \\
\text { Probability }\end{array}$ & Value & \\
\hline$R^{2}$ & .586 & $\mathrm{p}<$ \\
.0001 & & $\mathrm{p}<.01$ \\
\hline Pearson's Correlation & .765 & $\mathrm{p}$ \\
\hline
\end{tabular}

The table 13 presents the analysis for H1a. $\mathrm{R}^{2}$ is $.586, p$-value is small $p<.0001$, therefore null hypothesis is rejected. Additionally Figure 11 shows $R^{2}$ value of .586 , meaning the model (line) accounts for $59 \%$ of variability about the mean and Pearson's Correlation noted in Table 13 scored $.765(p<.01)$ indicating a strong linear association meaning as competence increases, psychological contracts increase.

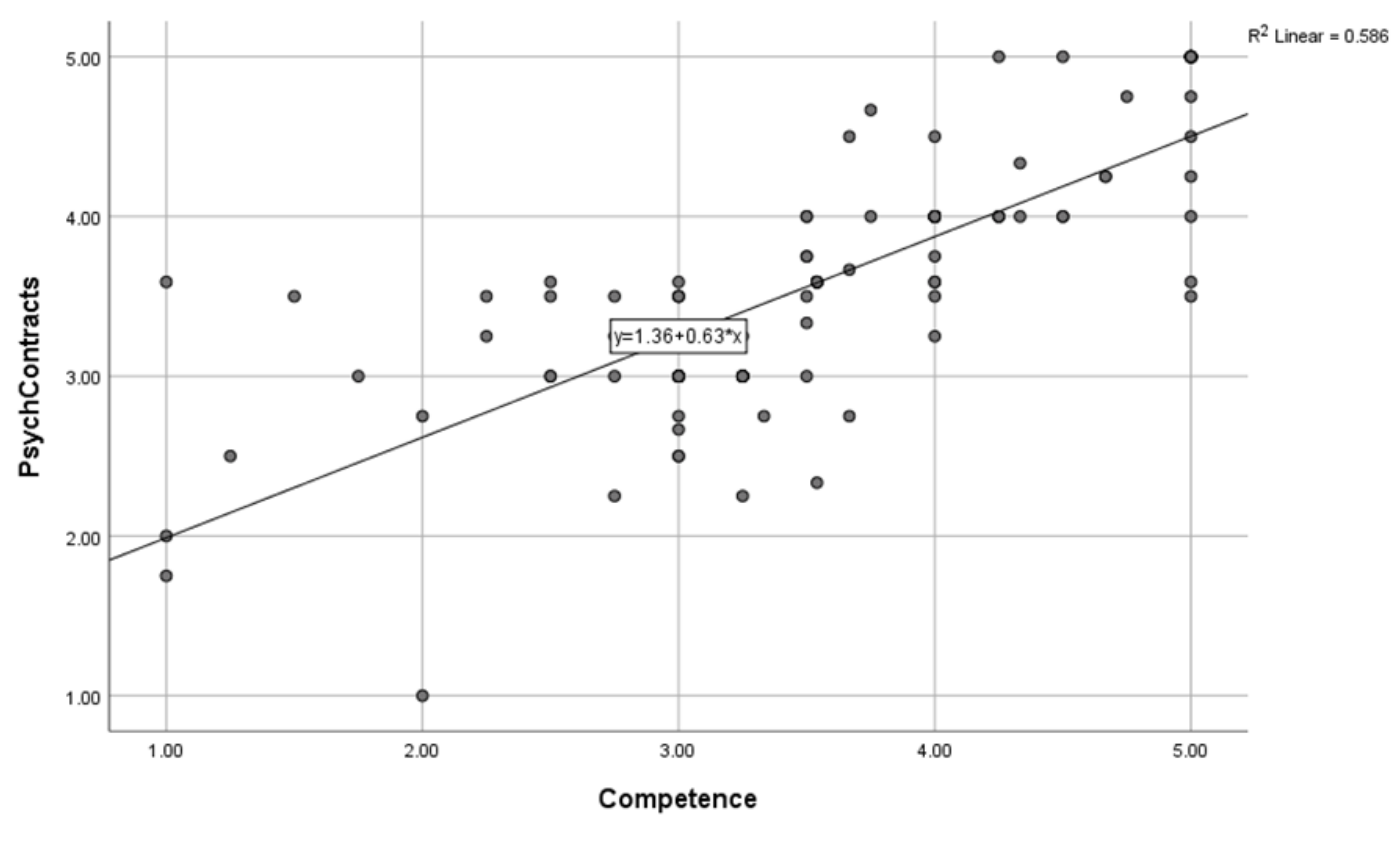

Figure 3.

Figure 3. Graph demonstrating relationship between Competence and Psychological Contracts. Scatter plot H1a 


\section{The impact of organizational trust on \\ Dr. Ayman Mobarez}

Table 9

Statistical Data Question 2 - Hypothesis 1b. Openness and Honesty is Positively Related to Psychological Contracts.

\begin{tabular}{|lcc|}
\hline $\begin{array}{l}\text { Openness and Honesty - Psych Contracts } \\
\text { Probability }\end{array}$ & Value & \\
\hline$R^{2}$ & .549 & $\mathrm{p}<$ \\
.0001 & & $\mathrm{p}<$ \\
\hline $\begin{array}{l}\text { Pearson's Correlation } \\
.01\end{array}$ & .741 & \\
\hline
\end{tabular}

Table 14 presents the analysis for H1b. $\mathrm{R}^{2}$ is $.549, p$-value is small $p<$ .0001 , therefore null hypothesis is rejected. Additionally, Figure 12 shows $R^{2}$ scores .549 meaning the model (line) accounts for $55 \%$ of variability about the mean and Pearson's Correlation noted in Figure 12 of .741 with $p<.01$ indicating a strong linear association su ch that as Openness and Honesty increases, Psychological Contracts also increases

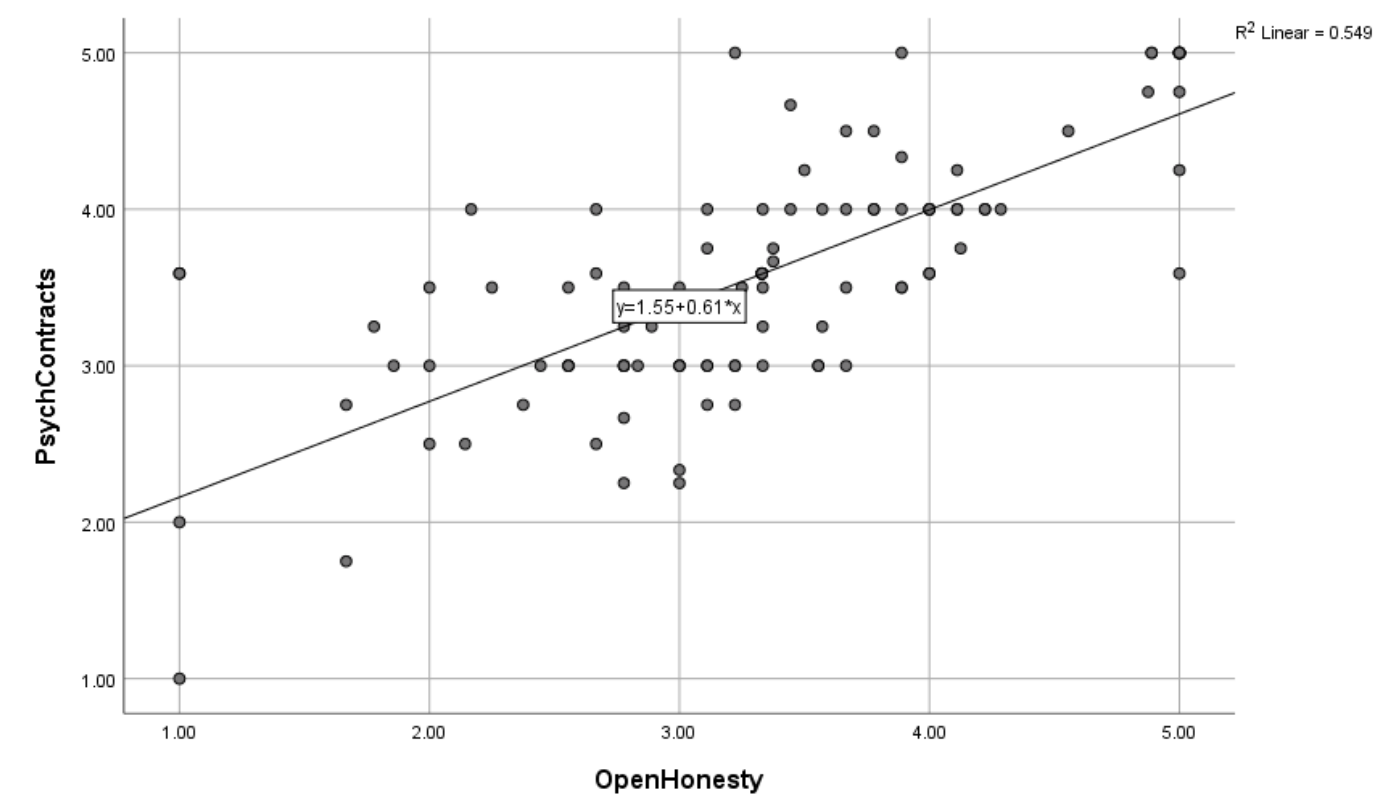

Figure 4

Figure 4. Graph demonstrating the relationship between Openness \& Honesty and Psychological Contracts. Scatter plot H1b. 


\section{The impact of organizational trust on \\ Dr. Ayman Mobarez}

Table 10 Statistical Data Question 2 - Hypothesis 1c. Concern is positively related to

Psychological Contracts

\begin{tabular}{|lcc|}
\hline Concern - Psych Contracts & Value & Probability \\
\hline$R^{2}$ & .574 & $p<.0001$ \\
\hline Pearson's Correlation & .864 & $p<.01$ \\
\hline
\end{tabular}

Table 10 presents the analysis for $\mathrm{H} 1 \mathrm{c} . \mathrm{R}^{2}$ is $.574, p$-value is small $\mathrm{p}<$ .0001 , and therefore null hypothesis is rejected. Additionally Figure 13 shows $R^{2}$ scores .574 meaning the model (line) accounts for $57 \%$ of variability about the mean and Pearson's Correlation value of .864 ( $p$ $<.01)$ indicating a strong linear association such that as Concern increases, Psychological Contracts also increases.

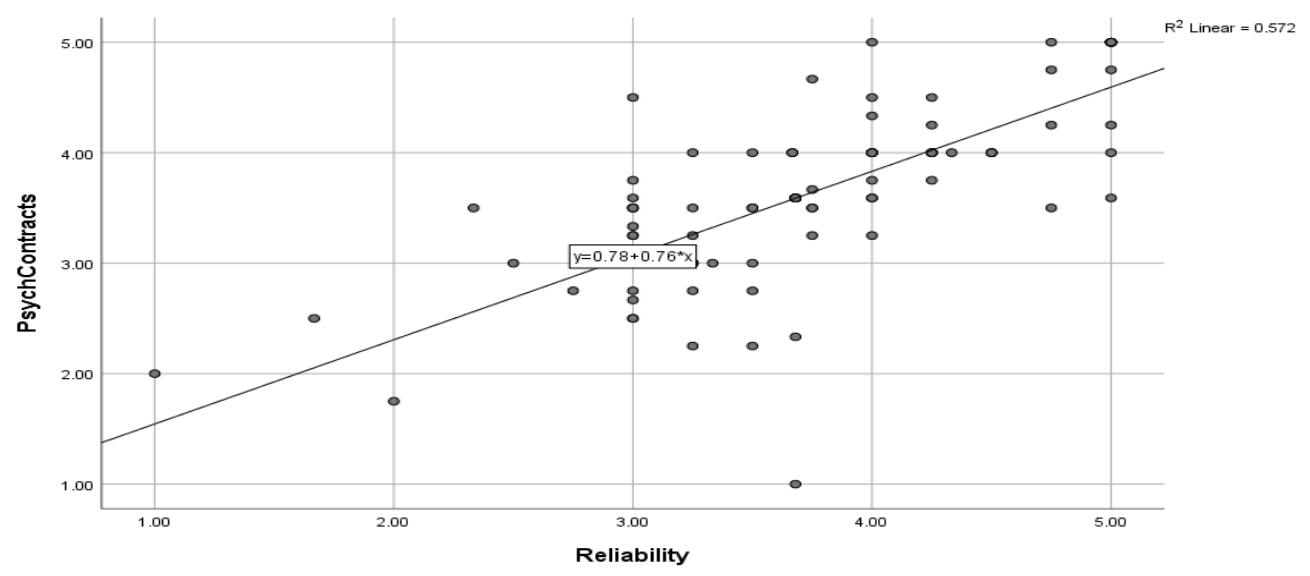

Figure 5

. Graph demonstrating the relationship between Reliability and Psychological

Contracts. Scatter Plot H1c

Table 11

Statistical Data Question 2 - Hypothesis 1e. Identification is Positively Related to Psychological

Contracts.

\begin{tabular}{|lc|}
\hline Identification - Psych Contracts & Value \\
Probability & \\
\hline$R^{2}$ & .578 \\
$p<.0001$ & .818 \\
\hline $\begin{array}{l}\text { Pearson's Correlation } \\
p<.01\end{array}$ \\
\hline
\end{tabular}

Table 11 presents the analysis for H1e. $\mathrm{R}^{2}$ is $.578, p$-value is small $p<$ .0001 , and therefore null hypothesis is rejected. Additionally Figure 


\section{The impact of organizational trust on \\ Dr. Ayman Mobarez}

10 shows $R^{2}$ scores .578 meaning the model (line) accounts for $58 \%$ of variability about the mean and Pearson's Correlation value of .818 ( $p$ $<.01$ ) indicating a strong linear association such that as Identific ation increases, Psychological Contracts also increases.

\section{- Limitations of the study}

Although the door was opened sharing insight into organizational relationships with

Respondents in the Egypt, the results may differ and not be applicable in other countries.

These results may not be applicable as a "blanket" in understanding organizational relationships and psychological contracts with all Educational and learning organization in Egypt. Simply because there are different types of Educational and learning organization.

Both researchers assumed that CIC elshikh Zayed and New Cairo Branch are heavily resourced organizations that create significant trust, status and reputation that arbitrate between private Educational and learning organization.

\section{- Discussion of Findings}

The results from this research fill a gap in the research literature and offer scholars and practitioners insight into organizational trust between Employee and educational and learning organization.

This research is important as educational and learning are organizations that are critically important that work at the interface of society and industry and surprisingly little research has been performed to understand them (Rajwani, et. al., 2018)

Just as past research has shown a relationship between organizational trust and

Psychological contracts between (a) employees and organizations and (b) customers and organizations, the results discussed above show there is a relationship between organizational trust and psychological contracts in the organizational context of Trade educational and learning organization and their members .

. This was demonstrated by the strong linear relationship between with $R^{2}$ scores $60 \%$ with a beta of .667 meaning for every 1 -point increase 


\section{The impact of organizational trust on \\ Dr. Ayman Mobarez}

in organizational trust results in a .667 - point increase in psychological contracts.

Pearson's correlation also scores .771 illustrating a strong positive correlation. Organizations can now understand if organizational trust diminishes between members and educational and learning organization psychological contracts fade which would lead the member to pull away from the educational and learning organization and possibly seek out another organization to join.

This research also determined that, within the context of educational and learning organization and their members, an organizational trust construct provides a stronger prediction of psychological contracts when compared to the prediction of the underlying organizational trust dimensions:

Competence, openness/honesty, and reliability, in trade associations. $R^{2}$. scores highest at $60 \%$ over the 3 underlying organizational trust dimensions and Pearson's correlation scores parallel in ranking from highest to lowest. 


\section{The impact of organizational trust on \\ Dr. Ayman Mobarez}

\section{REFERENCES :}

Achilleas, K. (2014). Designing better questionnaires: Demographic data. Accessed online at:

https://achilleaskostoulas.com/2014/01/28/designing-better-questionnairesdemographicdata/

Anderson, N., \& Schalk, R. (1998). The psychological contract in retrospect and prospect.

Journal of Organizational Behavior, 19, 637.

Argento, D., \& Peda, P. (2015). Interactions fostering trust and contract combinations in local

public services provision. The International Journal of Public Sector Management, 28(4),

335-n/a. Retrieved from

http://search.proquest.com/docview/1726844849?accountid=28844

Argyris, C. (1960). Understanding organisational behaviour. Homewood, Illinois: Dorsey Press.

Axelrod, R. (1984). The evolution of cooperation. New York, NY: Basic books.

Baker, H. G. (1996). The psychological contract between employer and employee. Psychology,

33(3), (pp. 16-30).

Baksh, Abdul M. (2010). Organizational commitment of managerial employees: a unified theory

and antecedents. (Unpublished doctoral dissertation). University of Southern

Queensland, Australia.

Barnard, C.I. (1938). The Functions of the Executive. Cambridge, MA: The Harvard Press.

Battisti. M., \& Perry, M. (2015). Small enterprise affiliations to business associations and the

collective action problem revisited. Small Business Economics, 44(3), (pp. 559-576).

Doi:10.1007/s11187-014-9607-z

Barnett, W. P., Mischke, G. A. \& Ocasio, W. (2010). The Evolution of collective strategies

among organizations. Organizational Studies, 31, (pp. 777-805).

Bennett, R., \& Ramsden, M. (2007). The contribution of business associations to SMEs: strategy,

bundling or reassurance? International Small Business Journal, 25(1), (pp. 49-76).

doi:10.1177/0266242607071781. 


\section{The impact of organizational trust on \\ Dr. Ayman Mobarez}

Bentler, Peter M. (2009). Alpha, Dimension-Free, and Model-Based Internal Consistency

Reliability. Psychometrika, 74, 137. https://doi.org/10.1007/s11336-0089100-1

Bromiley, P., \& Cummings, L.L. (1992). Transaction Cost in Organizations with Trust.

(Discussion Paper \#128). Minneapolis: University of Minnesota, Strategic Management

Research Center.

Bureau of Labor Statistics. "Campus Explorer" Real Estate Appraisers/Assessors Overview.

Accessed online 1/11/2017 at: https://www.bls.gov/ooh/constructionandextraction/

construction-and-building-inspectors.htm

Burton, R.M. \& Obel. B (2018). The Science of Organizational Design: Fit Between Structure

and Coordination. Journal of Organizational Design, 7:5. https://doi.org/10.1186/s41469-

018-0029-2

Butter, F. \& Mosch, R. (2003). Trade, Trust and Transaction Cost. (Discussion paper \# 03-

082/3) accessed at IDEAS at UConn. Department of Economics.

http://ideas.repec.org/p/dgr/uvatin/200382.html

Brockner, J., Phyllis, S.A., Daly, J.P., Tyler, T., \& Martin, C. (1997). When trust matters: The

moderating effect of outcome favorability. Administrative Science Quarterly Ithaca,

42(3), (pp. 558-583).

Bureau of Labor Statistics U.S. Department of Labor, Occupational Outlook Handbook, 2016-

2017 Edition, Listed under Construction and Building Inspectors at;

https://www.bls.gov/ooh/construction-and-extraction/construction-and-

buildinginspectors.

htm

Byrne, J. (2002). Restoring trust in corporate America. Business must lead the way to real

reform. Business Week, Cover Story. June 24, 2002.

https://www.bls.gov/ooh/construction-and-extraction/construction-and-

buildinginspectors.

htm

Caldwell, C. (2001). Organizational trustworthiness: A Developmental model. (Unpublished 


\section{The impact of organizational trust on \\ Dr. Ayman Mobarez}

doctoral dissertation). Washington State University.

Caldwell, C., \& Clapham, S.E. (2003). Organizational trustworthiness: An international

perspective. Journal of Business Ethics. Volume 47 (Iss. 4), (p. 349).

Caldwell, C., \& Jeffries, F.L. (2001). Ethics, norms, dispositional trust, and context: Components

of the missing link between trustworthiness and trust. Presented at the Eighth Annual

International Conference on Ethics in Business. (De Paul University, Chicago, IL).

Cheng-Hsien, L. (2016). Confirmatory factor analysis with ordinal data: Comparing robust

maximum likelihood and diagonally weighted least squares. Behavior Research Methods.

48(3), (pp. 936-949).

Choduba, B. (2011). How much time are respondents willing to spend on your survey? Survey

Monkey Chief Revenue Officer. Accessed online at:

https://www.surveymonkey.com/blog/2011/02/14/survey_completion_time s/

Conway, N., \& Briner, R. B. (2002). Full-time versus part-time employees: Understanding the

links between work status, the psychological contract, and attitudes.

Journal of

Vocational Behaviour, 61, (pp. 279-301).

Coyle-Shapiro, Jacqueline A-M. \& Conway, N. (2005). Exchange relationships: Examining

psychological contracts and perceived organizational support. Journal of Applied

Psychology. 90(4), (pp. 774-781).

Creed, W.E.D., \& Miles, R.E. (1996). Trust in organizations: A Conceptual framework linking

organizational forms, managerial philosophies, and the opportunity costs of controls. In

R.M. Kramer and T.R. Tyler, Trust in organizations: Frontiers of theory and Research

(pp. 16-38). Thousand Oaks, CA: Sage.

Creswell, J. W. (2005). Educational research: Planning, conducting, and evaluating quantitative

and qualitative research (2nd ed.). Upper Saddle River, NJ: Pearson Merrill Prentice Hall. 


\section{The impact of organizational trust on \\ Dr. Ayman Mobarez}

Dahlstrom, R., Nygaard, A., Kimasheva, M., \& Ulvnes, A. M. (2014). How to recover trust in

the banking industry? A game theory approach to empirical analyses of bank and

corporate customer relationships. The International Journal of Bank Marketing, 32(4),

(pp. 268-278). doi:http://dx.doi.org/10.1108/IJBM-03-2014-0042

Daley, D. (1991). Management practices and the uninvolved manager: The effect of

supervisory attitudes on perceptions of organizational trust and change

orientation. Public Personnel Management, 20(1), (pp. 101-113).

Das, T.K. \& B. Teng. (2001). Between Trust and Control: Developing Confidences in Partner

Cooperation in Alliances. Academy of Management Review, Vol. 23, No. 3

Deutsch, Morton (1958). Trust and suspicion. Journal of Conflict Resolution, 2, (pp. 265-279).

Dibben, M.R. (2000). Exploring interpersonal trust in the entrepreneurial venture. Houndsmills,

Basingstoke, Hampshire, UK: Macmillan Press.

Eckerd, S., Boyer, K. K., Qi, Y., Eckerd, A., \& Hill, J. A. (2016). Supply chain psychological

contract breach: An experimental study across national cultures. Journal of Supply Chain

Management, 52(3), (p. 68).

Elangovan, A.R., \& Shapiro, D.L. (1998). Betrayal of trust in organizations. Academy of

Management Review. 23 (3) (p. 547).

Federal Trade Association FTC, CAN-SPAM Act. (2003). Signed into law Dec 16, 2003 by

President George W. Bush establishing US standards of sending commercial email

allowing enforcement by the FTC. Retrieved online 7/24/2016 from:

https://www.ftc.gov/tips-advice/business-center/guidance/can-spam-act-

complianceguide-

business

Follett, Mary Parker. (1918). The New State. Accessed online at:

http://www.channelingreality.com/Education/Mary_Parker_Follett_New_St ate.pdf

Fornel, C. \& Larcker, David F. (1981). Structural Equation Models with Unobservable Variables

and Measurement Error: Algebra and Statistics. Journal of Marketing Research,.18(3), 


\section{The impact of organizational trust on \\ Dr. Ayman Mobarez}

(pp. 382-388).

Frost, Jim. (2013). Regression analysis: How do I interpret $R^{2}$ and assess the goodness of fit.

Retrieved online from: http://blog.minitab.com/blog/adventures-instatistics-2/regressionanalysis-

how-do-i-interpret- $\mathrm{R}^{2}$ uared-and-assess-the-goodness-of-fit

Gambetta, D. (1988). Can we trust? In Trust: Making and Breaking Cooperative Relations (pp.

213-237). Oxford UK: Basil Blackwell.

Graham, P. (1995). Mary Parker Follett -prophet of management: A Celebration of writings

from the 1920s. Boston, MA: Harvard Business School Press.

Gromicko, N. \& Ferry, J. (2017). Forms of Inspection Business Ownership and Structure.

International Association of Certified Home Inspectors. Accessed online at: https://www.nachi.org/inc.htm

Harrington, M. (2017). Survey: Peoples trust has declined in business, government and NGOs.

Harvard Business Review. Economics \& Society. Retrieved from:

https://hbr.org/2017/01/survey-peoples-trust-has-declined-in-business-

mediagovernment-

and-ngos

Hult, M., Stafford, E.,Walker, B., \& Reingen, P. (2000). Case study:

Defining the social network

of a strategic alliance, Sloan Management Review, 41 (pp. 51-62).

Hosmer, L.T. (1995). Trust: The connecting link between organizational theory and behavior.

Academy of Management Review, 20(2), (pp. 379-404).

Isaksson, K., Bernhard, C., Claes, R., De Witte, H., Guest, D., Krausz, M., Mohr, G., Peiró, J.M.,

\& Schalk, R. (2003). Employment contracts and psychological contracts in Europe.

Results from a pilot study. Med svensk sammanfattning. SALTA Report 2003: I. Joint

Programme for Working Life Research in Europe.

Jones, G.R., \& George, J.M. (1998). The experience and evolution of trust: Implications for

cooperation and teamwork. Academy of Management Review. 23(3), (p. $351)$.

Karl, Katherine A. (2000). Trust and Betrayal in the Workplace: Building Effective relationships 


\section{The impact of organizational trust on \\ Dr. Ayman Mobarez}

in Your Organization. The Academy of Management Executive, 14(2), (pp. 133-134).

Koçak, Ö. E. (2016). How to enable thriving at work through organizational trust. International

Journal of Research in Business and Social Science, 5(4), (pp. 40-52).

doi:http://dx.doi.org/10.20525/ijrbs.v5i4.580

Kramer, R.M. (1996). Divergent realities and convergent disappointments in the hierarchic

relation: Trust and the intuitive auditor at work. In R.M. Kramer and T. Tyler (Eds.),

Trust in Organizations: Frontiers of Theory and Research (pp. 216-245)

Thousand Oaks,

CA: Sage Publications, Inc.

Krishnan, R., Marinich, E., \& Shields, M. (2012). Participating budgeting, psychological

contracts, and honesty of communication. Paper presented at Michigan State University,

June 7, 2012.

Kurstedt, H. (2002, October). How do we design for trust? Proceedings from the 2002 American

Society of Engineering Management National Conference, Tampa, FL.

Larrain, M. \& Prüfer, J. (2015). Trade associations, lobbying and endogenous institutions.

Journal of Legal Analysis, 7(2) (pp. 467 - 516).

Lawton, T., Rajwani, T, \& Minto, A. (2018). Why trade associations matter: Exploring function,

meaning, and influence. Journal of Management Inquiry.27(1), (9pp. 5 - 9)

Lee, C., Song, H., Lee, H., \& Lee, S. (2013). The impact of CSR on casino employees'

organizational trust, job satisfaction, and customer orientation: An empirical examination

of responsible gambling strategies. International journal of hospitality

management.

Volume 33, June 2013, (pp. 406-415). Elsevier. doi:10.1016/j.ijhm.

2012.10.011

Levinson H., Meckler, M., \& Drake, B.H. (2003). Putting psychology back into psychological

contracts. Journal of Management Inquiry. Volume 12, issue 3, (pp. 217228).

Levinson, H., Price, C. R., Munden, K. J., \& Solley, C. M. (1962). Men, management and mental

health. Cambridge, MA: Harvard University Press. 


\section{The impact of organizational trust on \\ Dr. Ayman Mobarez}

Limerick, D., \& Cunnington, B. (1993). Managing the New Organization: A Blueprint for

Networks and Strategic Alliances. San Francisco: Jossey-Bass.

Mamonov, S. (2014). Psychological contracts in information exchanges. (Unpublished doctoral

dissertation). The City University of New York, New York City, New York.

Mayer, R.C., Davis, J.H., \& Schoorman, F.D. (1995). An integrative model of organizational

trust. Academy of Management Review, 20(3),709-734.

McAllister, D.J. (1995). Affect - and cognition - based trust as foundations for interpersonal

cooperation in organizations. Academy of Management Review,38(1),24-59

McDermott, A. M., Conway, E., Rousseau, D. M., \& Flood, P. C. (2013).

Promoting effective

psychological contracts through leadership: The missing link between HR strategy and

performance. Human Resource Management, 52(2), 289-310. oi:10.1002/hrm.21529

McGregor, D. (1967). The professional manager. New York: McGraw-Hill.

Meyer, R. (2018). Why do people and companies join trade associations? Computing Technology

Industry Association (CompTIA) Newsroom/Blog. Accessed online at https://www.comptia.org/about-us/newsroom/blog/comptia-

blog/2018/03/01/why-dopeople-

and-companies-join-trade-associations

Miles, R.E., \& Creed, W.E.D (1995). Organizational Forms and Managerial Philosophies: A

descriptive and Analytical Review. In B.M. Staw and L.L. Cummins (Eds.) Research in

Organizational Behavior, Volume 17. (333-372). Greenwich, CT: JAI.

Morrison, Elizabeth Wolfe, \& Robinson, Sandra L. (1997). When employees feel betrayed: A

model of how psychological contract violation develops. Academy of Management

Review, 22(1), pp. 226-256

Morrison, Ann. M. (1992) Leadership Diversity as Strategy. In The New

Leaders: Guidelines on

leadership diversity in America. (11-28). San Francisco: Jossey-Bass. Philip R. Harris

Nyhan, R., \& Marlowe, H. (1997). Development and psychometric properties of the 


\section{The impact of organizational trust on \\ Dr. Ayman Mobarez}

organizational trust inventory. Evaluation Review, 21(5), 614-635.

Rajwani, T., Lawton, T., \& Phillips, N., (2015). The "Voice of Industry":

Why management

researchers should pay more attention to trade associations. Strategic

Organization, 13(3),

$224-232$.

Raykov, Tenko. (2001). Bias of Coefficient for fixed congeneric measures with correlated

Errors. Applied Psychological Measurement, 25(1), 69 - 76.

Reina, D.S., \& Reina, M.L. (1999). Trust \& Betrayal in the Workplace:

Building Effective

Relationships in Your Organization. Berrett-Koehler Publishers, Inc. Oakland, CA. USA.

Ring, P. S., Ring, P. S., \& Van De Ven, A. H. (1994). Developmental processes of cooperative

interorganizational relationships The Academy of Management Review,

Volume 19, No. 1

(Jan., 1994), pp. 90-118. doi:10.5465/AMR.1994.9410122009

Robinson, S. L. (1996). Trust and breach of the psychological contract.

Administrative Science

Quarterly, 41, pp. 574-599.

Robinson, S. L., Kraatz. M., \& Rousseau, D. M. (1994). Changing

obligations and the

psychological contract: a longitudinal study. Academy of Management Journal, 37, pp.

137-152.

Roehling, M. V. (1997). The origins and early development of the psychological contract

construct. Journal of Management History, 3(2), pp. 204-217.

Rousseau, Denise M. (1995). Psychological Contracts in Organizations.

Understanding Written

and Unwritten Agreements. Thousand Oaks, CA: Sage Publications.

Rousseau, Denise M. (1989). Psychological and implied contracts in organizations. Employee

Responsibilities and Rights Journal, 2,121-139.

Rousseau, Denise M. \& Judi McLean Parks. (1994). The contracts of individuals and

organizations. In L.L. Cummings and Barry M. Staw (eds.), Research in Organizational

Behavior, Vol. 15 (1-43). Greenwich, CT: JAI Press.

Scott, D. (1981). The development of four new organizational measures of trust. In D. 


\section{The impact of organizational trust on \\ Dr. Ayman Mobarez}

Ray (Ed.), The relationship between theory, research, and practice: An assessment of fundamental problems and their possible resolution (107109).

Sinclair, M., Jr. (2013). The influence of trust and affective organizational commitment on intent

to leave. (Doctoral dissertation), Retrieved from ProQuest Central; ProQuest

Dissertations \& Theses Global (1318534656).

https://search.proquest.com/docview/1318534656? accountid=28844

Smithson, J. \& Lewis, S. (2003). The Psychological Contract. A Sloan work and Family

Encyclopedia Entry. Accessed online at:

http://www.bc.edu/bc_org/avp/wfnetwork/rft/wfpedia/wfpPCent.html\#

Tavakol, M., \& Dennick, R. (2011). Making sense of Cronbach's alpha. International Journal of

Medical Education, 2, pp. 53-55.

Taylor, B. (2001). Theory of Reasoned Action. Paper prepared for Dr. Leckenby. Accessed

online

at

http://www.ciadvertising.Org/student_account/fall_01/adv382j/brent/yes.ht $\mathrm{ml}$

Tekleab, A. G., \& Taylor, M. S. (2003). Aren't there two parties in an employment relationship?

Antecedents and consequences of organization-employee agreement on contract

obligations and violations. Journal of Organizational Behavior, 24(5), 585608.

doi:10.1002/job.204

Tekleab, A.G., Takeuchi, R. \& Taylor S. M. (2005) Extending the chain of relationships among

organizational justice, social exchange, and employee reactions: The Role of contract

violation. Academy of Management Journal, 48(1) 146-157.

Trussell, G. (2015). Organizational trust as a moderator of the relationship between burnout and

intentions to quit. (Doctoral dissertation) Retrieved from ProQuest Dissertations \&

Theses Global. (1686537066).

http://search.proquest.com/docview/1686537066?accountid=28844

Tyler, T., \& Kramer, R. (1996). Whither trust? In R. Kramer \& T. Tyler (Eds.), Trust in 


\section{The impact of organizational trust on \\ Dr. Ayman Mobarez}

Organizations (1-15). Thousand Oaks, CA: Sage.

US Census Bureau. (2010). Population Distribution in the United States and Puerto Rico map

(also referred to as the "Nighttime Map"). Retrieved online from

https://www.census.gov/geo/maps-data/maps/2010popdistribution.html

Velez, P., \& Strom, T. (2012). Organization development journal: Effects of organizational trust.

Organization Development Institute,30(2),

Winterstein, A.G. \& Kimberlin, C.L. (2008). Validity and reliability of measurement instruments

used in research. American Journal of Health-System Pharmacy, 65(23), (pp. 2276-

2284). DOI: https://doi.org/10.2146/ajhp070364

Yarn, D.H. \& Ide, W.R. III. (2003). Public independent fact-finding: A trust-generating

institution for an age of corporate illegitimacy and public mistrust. Vanderbilt Law

Review, 56(4), (p. 112).

Zane, L. J. \& Masterfano, M. K. (2011). Effect of participation in business membership

organizations on the size and occupational diversity of entrepreneurs' core business

discussion network. Journal of Small Business Strategy, (pp. 71-91).

- Zagenczyk, T., Gibney, R., Few, W., \& Scott, K. (2011). Psychological contracts and

organizational identification: the mediating effect of perceived organizational

support. Journal of Labor Research, 32(3), (pp. 254-281). doi:10.1007/s12122-011-9111

- Zia, Y. A., \& Khan, M. Z. (2014). Organizational trust: A cultural perspective. The Journal of

Humanities and Social Sciences, 22(2), (pp. 127-134). Retrieved from

http://search.proquest.com/docview/1654867630?accountid=28844

- Ekvall, G.; Ryhammar, L. The creative climate: Its determinants and effects at a Swedish university.

Creat. Res. J. 1999, 12, 303-310.

- Molm, L.D.; Collett, J.L.; Schaefer, D.R. Building Solidarity through Generalized Exchange: A Theory of 


\section{The impact of organizational trust on \\ Dr. Ayman Mobarez}

Reciprocity1. Am. J. Sociol. 2007, 113, 205-242.

- Aryee, S.; Budhwar, P.S.; Chen, Z.X. Trust as a mediator of the relationship between organizational justice

and work outcomes: Test of a social exchange model. J. Organ. Behav. 2002, 23, 267-285.

- Knippenberg, D.; Schie, E. Foci and correlates of organizational identification. J. Occup. Organ. Psychol. 2000, 73, 137-147.

- Barczak, G.; Lassk, F.; Mulki, J. Antecedents of team creativity: An examination of team emotional intelligence, team trust and collaborative culture. Creat. Innov. Manag. 2010, 19, 332-345.

- Liu, Y.; Loi, R.; Lam, L.W. Linking organizational identification and employee performance in teams:

The moderating role of team-member exchange. Int. J. Hum. Resour. Manag. 2011, 22, 3187-3201.

- Caldwell, C. (2001). Organizational trustworthiness: A Developmental model. (Unpublished doctoral dissertation). Washington State University.

- Molm, L.D.; Collett, J.L.; Schaefer, D.R. Building Solidarity through Generalized Exchange: A Theory of Reciprocity1. Am. J. Sociol. 2007, 113, 205-242.

- Blau, P.M. Exchange and Power in Social Life; Transaction Publishers: Piscataway, NJ, USA, 1964.

- McAllister, D.J. (1995). Affect - and cognition - based trust as foundations for interpersonal cooperation in organizations. Academy of Management Review,38(1),24-59

- Brockner, J., Phyllis, S.A., Daly, J.P., Tyler, T., \& Martin, C. (1997). When trust matters: The moderating effect of outcome favorability. Administrative Science Quarterly Ithaca, 42(3), (pp. 558-583).

- Argyris, C. (1960). Understanding organizational behavior. Homewood, IL.: Dorsey Press.

- Rousseau, D. M. (1990). New hire perceptions of their own and their employer's obligations: A study of psychological contracts. Journal of Organizational Behavior, 11, 389-400. 


\section{The impact of organizational trust on \\ Dr. Ayman Mobarez}

- Rousseau, D. M. (1995). Psychological contracts in organizations: Understanding written and unwritten agreements. Thousand Oaks, CA: Sage Publications.

- Rousseau, D. M. (2001). Schema, promise and mutuality: The building blocks of the psychological contract. Journal of Occupational and Organizational Psychology, 74, 511-541.

- Koh, W. L., \& Yer, L. K. (2000). The impact of the employeeorganization relationship on temporary employees' performance and attitude: Testing a Singaporean sample. The International Journal of Human Resource Management, 11(2), 366 - 387.

- Robinson, S. L., Kraatz, M. S., \& Rousseau, D. M. (1994). Changing obligations and the psychological contract: A longitudinal study. Academy of Management Journal, 37(1), 137-152.

- Smithson, J. \& Lewis, S. (2003). The Psychological Contract. A Sloan work and Family Encyclopedia Entry. Accessed online at:

- http://www.bc.edu/bc_org/avp/wfnetwork/rft/wfpedia/wfpPCent.htm l\# 